の細胞から遊離し肺流血中に入ったことが可能性として 考光られる。そこで， $\mathrm{O}_{3}$ または $\mathrm{NO}_{2}$ をモルモットの摘 出肺に吸入させながら，肺動脈から肺静脈へと灌流し， 灌流液中へのヒスタミン遊離について，Air 吸入させ た対照群と比較検討を行った。体重 $350 \mathrm{~g}$ 前後のモルモ ットの頸静脈にヘパリンを注入した後，肺を摘出し，恒 温槽内にて，気管よりガスまたは Airをポンプにて， 一回換気量 $20 \mathrm{~m} l$ ，一分間 25 回で 90 分吸入させた。 カテ ーテルを肺動脈に大れ, polyvinylpyrrolidone を Tyrode 液に加えたもので灌流した。一分間 $0.8 \mathrm{~m} l$ で肺を灌流 乙, 肺静脈からの排出液中のヒスタミン量を Shore ら の管光光度法により定量した．灌流液中のヒスタミン量 は，気管から Air 定吸入させた場合， $3.5 \mu \mathrm{g}$ であった のに対して， $\mathrm{O}_{3}$ の場合 $10.5 \mu \mathrm{g}$ で有意の差を示したが， $\mathrm{NO}_{2}$ の場合は，3.8 $\mu \mathrm{g}$ で差はみられなかった．灌流液 中のヒスタミン量と灌流後の肺代残ったヒスタミン量の 和を，灌流前に肺に含まれていたヒスタミン量として， こ机を $100 \%$ とすると，灌流液中には，Air の場合に7.7 \%のヒスタミンが流出したのに比較して， $\mathrm{O}_{3}$ の場合は, $22.6 \%, \mathrm{NO}_{2}$ の場合は， $8.5 \% て ゙ あ っ た ． \mathrm{O}_{3}$ の場合は 明らかに，有意差をもって，灌流液中にヒスタミンが遊 離したが， $\mathrm{NO}_{2}$ の場合には対照群と差がなかった。肺 内のヒスタミン作用は， $\mathrm{O}_{3}$ のもつ作用の一つであり， $\mathrm{NO}_{2}$ には見られない作用である。肺水腫の発生のメ力 ニズムもかならずしも， $\mathrm{O}_{3}$ と $\mathrm{NO}_{2}$ の場合では同じと は考えら机ない。

\section{3. $0_{3}$ 連続吸入によるモルモットの肺のヒスタミン} 量

鈴木聰男（医歯大衛生）

深瀬 治 (大阪市衛研) 横山栄二 (公衆衛生院労働)

$\mathrm{O}_{3}$ 4-8 ppm をモルモットに吸入させることによっ て，肺水腫の発生を認めると同時に，柿内ヒスタミン含 量の減少がみられ，さらにモルモットの肺を摘出し，こ れを人工灌流液で灌流し，気管より $\mathrm{O}_{3}$ を吸入させるこ とによって，灌流液中へのヒスタミン遊離をみとめたこ とを以前報告した。本実験では比較的低濃度の $\mathrm{O}_{3}$ を 3 時間一回吸入した場合のモルモットの肺内ヒスタミン量 の変化を知り，また $\mathrm{O}_{3}$ をりか光し一回 3 時間づつ, 5 日間吸入乙た場合との比較を行った。体重 $350 \mathrm{~g}$ 前後 のモルモットを暴露箱に入れ，一群は 3 時間一回，他の
一群は一日一回 3 時間，連続して 5 日間， $\mathrm{O}_{3}$ 濃度 0.9 $\mathrm{ppm}$ 拉よび $2.5 \mathrm{ppm}$ を吸入させた。吸入直後に断頭 乙, 肺を摘出し, 肺重量測定後, Shore らの管光光度法 により肺内ヒスタミン含量を測定した。肺内ヒスタミン 含量は，肺 $1 \mathrm{~g}$ 当り量，肺全体量，および体重 $100 \mathrm{~g}$ 当 りの量抢の扔のについて比較を行った。 $\mathrm{O}_{3} 0.9 \mathrm{ppm} て ゙$ は，一回吸大でもくりか党し吸人でも，著明な肺水腫は みとめられず，肺のヒスタミン量も減少を示さなかっ た. $\mathrm{O}_{3}$ 濃度 $2.5 \mathrm{ppm}$ になると, 一回吸入の場 合 む, くりか光し吸入の場合も, 肺内のヒスタミン量は, 有意 差をもって減少した，一回吸大とくりか克し吸大でも， 肺重量はそ机程增加せず，また $\mathrm{O}_{3} 2.5 \mathrm{ppm}$ の場合は， 一回吸入之くりか元し吸大ともに，ヒスタミン減少は似 かよった傾向を示した，明らかな肺水腫を発生させるの は，少なくともこれ以上の濃度の $\mathrm{O}_{3}$ を，モルモットに 吸入させた場合であるうと考觉られる。またこの程度の $\mathrm{O}_{3}$ 濃度の場合は，くりかえし吸入させた場合でも，肺 内ヒスタミン量は，少なくとも5 日間の間は，隇少した ままであり，元通りの肺内ヒスタミン量に近づく傾向は 見られなかった。

\section{討 論}

友国勝磨：(岡山大公衛）： $\mathrm{O}_{3}$ の吸入濃度を $0.9 \mathrm{ppm}$ から $2.5 \mathrm{ppm}$ にされた理由は何ですか。

鈴木聰男 : $8 \mathrm{ppm}$ では著明な肺水腫と肺ヒスタミン量 の減少を認めたのでそれ以下とし，さらに大気中に発生 する可能性のある濃度として選えだ。

\section{4. メチルクロロホルム暴露後の呼気濃度について}

多田 治, 中明賢二, 深堀すみ江（学研）

メチルクロロホルム（MC）暴露の評価法に関して, 演者らは先に尿中代謝座物を指標とする検査法を検討 し，この穾験成績についてはすで報告した，その後， 呼気による暴露評洒法の検討を計画し，人工暴露室を用 いて以下の実験を行なった。

被験者には男子 2 名，女子 2 名を用い，平均約 195 , $375 ， 560 ， 830 \mathrm{ppm}$ の濃度で 1 日 2 時間ずつ4 日間く り返し暴露した。気中濃度の測定には検知管法, 比色法 (アルカリーピリジンーベンジン法)，ガスクロマトグラフ （G C ) 法を用い，比色法とGC法の測定值には大差の ないことを認めた，GC法のサンプルは塩化ビニリデン 製の袋内に採取するのがよく，袋内の濃度は25時間後に 
約 $5 \%$ の低下を示す程度であるが，注射器では，摺合わ せ部分を水でシールしても濃度の低下が大きかった。

被験者については，暴露終了後新鮮空気中で肺胞気を 袋内に呼出させ，GC法によって呼気中の MCを測定し た。呼気中に排泄される $\mathrm{MC}$ 濃度は，暴露終了直後に最 も高く, その後, 経時的に減少し, 性別による相違は認 められなかった．被験者 4 名の平均呼気濃度と暴露濃度 との関係をみると，暴露終了後60分以内では，呼気採取 時期により一定の比例関係が認められた。

男子 2 名については，暴露開始の日から 8 時間毎の尿 を8 日間続けて採取し，尿中TCA量をアルカリ・ピリ ジン・ベンジン法で測定した．㽷中のTCA量は暴露開 始後徐々に增加し，4〜5日目に最高となり，の台徐々 に減少する傾问であった。

\section{5. 砒化水素中毒に関する実験所研究}

\section{梶原忠政（熊大医公衛）}

䂤化水素 $\left(\mathrm{AsH}_{3}\right)$ は1775年 Scheele により最初に記 載された無色の気体で，元来無臭であるが，不純物のた め多くの場合ニンニク臭をもっている．発生機の水素が 碓素と化合してできるが，実際上は砒素を不純物として 含む金属に酸が接触して発生することが多い，極めて猛 毒（許容濃度は $0.05 \mathrm{ppm}$ ) であり，1815年 München の化学者 Gehlen が実験室でこのガスを吸入して死亡し たのが中毒の初めである。工策中毒としては Trost （1873）の報告が最初であるが, Muehlberger 等（1928） は文献中，247 例（うち死亡50例）を数え，Leschke （1923）は土業中毒のみで300例に達しているとし，しか も今日尚各地に散発している。わが国での報告は極めて 少なく，わづかに小林（1942）のものがあるにすぎな い. 砒化水素は砒素の化合物の中でも最も重篤な中毒を 抗こし，赤血球のへモグロビンに作用して，溶血，血色 素尿，黄淔等を起こす. 昭和 40 年 1 月，著者の関係する 某製鍊所に执いて教化水素中毒により33才の工員が発病 乙, 腰痛, 悪心澏吐, 血色素尿, 盆血, 黄疽, 层毒症等 の症状々現わし, 輸血, 人工腎藏, 腹膜灌流等を主とし た強力な治療により37日間生存したが，最後には真菌に よる肺化膿症を直接の死因として死亡するに至った。こ の症例の病状経過初よび病理解剖所見の評細については 「砒化水素中毒症の一部検例」として著者らが労働科学 第42巻第 6 号に発表したと和りである. 今回著者は，ご ゅうしまつ，マウス，ラット等を使用して吪化水素の毒
性を実験し，濃度预よびバク口時間と動物の生死，莫化 水銀検知紙の変化, 病理解剖所見, 薬剂の予防效果, 中 毒の早期発見法等について若干の知見を得，現場の衛生 管理の参考にすることが出来たので，これを報告する。

\section{6. アルカリろ紙法による作業環境中酸性ガスの測定 （第II報）フッ化水素（H F ) ガスの測定}

\section{由比顕之介，酒井 淳 (八幡製鉄病院労研課)}

前報に执いては，アルカリろ紙法による作業環 境中 $\mathrm{SO}_{2}$, 硫酸, $\mathrm{NO}_{2}, \mathrm{NO}_{3}, \mathrm{CrO}_{3}$ 特よびリン酸等酸 性 ガ ス，酸ミストの濃度測定に関する検討結果より，アルカ リろ紙法が以上の酸性ガス，酸ミストの測定に実用的方 法である事を報告した。本報ではアルカリろ紙法による HFガスの測定について検討した結果を報告する.

1.アルカリろ紙に吸着する $\mathrm{F}$ 量の定量は, SPADNS - Z r 法を改良した微量定量法により行う。この方法によ り蒸留操作を要せず迅懒定量ができる。

2. H F ガスは酸性ガスの中でアルカリろ紙に最も良 く吸着するので，24時間設置時においては，HF 0.01 $\mathrm{mg} / \mathrm{m}^{3}$ の低濃度環境まで測定しらる.また $10 \mathrm{mg} / \mathrm{m}^{3} の$ 高濃度環境にいたるまで環境 H F 濃度とアルカリろ紙吸 着量は直線関係を示し， 万紙吸着量 $\left(\mathrm{mg} / \mathrm{day} / 100 \mathrm{~cm}^{2}\right)$ より塄境がス濃度への換算にはろ紙吸着量に 0.1 を乗ず れば環境がス濃度 $\left(\mathrm{mg} / \mathrm{m}^{3}\right)$ がえられる。

3.アルカリろ紙に吸着する $\mathrm{F}$ 量は，同一環境では設 置時間に正比例して增加する，父のためろ紙設置時間を 一定にする必要はなく，作笠条件に応じて変える事がで きる. $0.1 \mathrm{mg} / \mathrm{m}^{3}$ 以下の低濃度罣境では 6 時間, $1 \mathrm{mg}$ | $\mathrm{m}^{3}$ 以上の高濃度環境では10〜60分の設置が適当である

4.アルカりろ紙に刘するHFガスの吸着性は, 温度 および湿度に関しては全然影響を受けない。したがって 温度および湿度に関する補正を要しない。 